\title{
OPEN Increase maize productivity and water use efficiency through application of potassium silicate under water stress
}

\author{
M. A. Gomaa ${ }^{1}$, Essam E. Kandil ${ }^{1 凶}$, Atef A. M. Zen El-Dein'², Mamdouh E. M. Abou-Donia², \\ Hayssam M. Ali ${ }^{3,4}$ \& Nader R. Abdelsalam ${ }^{5 凶}$
}

In Egypt, water shortage has become a key limiting factor for agriculture. Water-deficit stress causes different morphological, physiological, and biochemical impacts on plants. Two field experiments were carried out at Etay El-Baroud Station, El-Beheira Governorate, Agriculture Research Center (ARC), Egypt, to evaluate the effect of potassium silicate (K-silicate) of maize productivity and water use efficiency (WUE). A split-plot system in the four replications was used under three irrigation intervals during the 2017 and 2018 seasons. Whereas 10, 15, and 20 days irrigation intervals were allocated in main plots, while the three foliar application treatments of K-silicate (one spray at 40 days after sowing; two sprays at 40 and 60 days; and three sprays at 40,60, and 80 days, and a control (water spray) were distributed in the subplots. All the treatments were distributed in 4 replicates. The results indicated that irrigation every 15 days gave the highest yield in both components and quality. The highly significant of (WUE) under irrigation every 20 days. Foliar spraying of K-silicate three times resulted in the highest yield. Even under water-deficit stress, irrigation every fifteen days combined with foliar application of K-silicate three times achieved the highest values of grain yield and its components. These results show that K-silicate treatment can increase WUE and produce high grain yield requiring less irrigation.

Maize (Zea mays L.) is considering the third highest important staple food crop by area and production in Egypt and the world. In Egypt, the cultivated area occupies approximately 935,778 ha, which produces up to seven million tons of grains with an average yield of $7.60 \mathrm{ton} / \mathrm{ha}^{1}$. Yellow maize cultivation in Egypt is used in the production of food products to reduce imports of meat and milk ${ }^{2,3}$.

In Egypt, the water resources are limited and restrict many crop production especially in newly reclaimed lands due to the establishment of intensive agricultural production in the Nile Delta and valley area. The agricultural area consumes more than $84 \%$ of the available water resources ${ }^{4,5}$. Three factors affect the agricultural water use such as the water needs (evapotranspiration) by the crop, water availability, and water holding capacity of the soil ${ }^{6}$. Also, climate changes, such as altered precipitation and temperature systems, have had negative effects on crop quantity and yields. Seasonal global temperatures have increased, with even larger changes observed in several regions ${ }^{7}$. About $30 \%$ of the variation in average global yields of wheat, rice, maize, soybeans, barley, and sorghum resulted from seasonal precipitation and temperature changes ${ }^{8}$. The uneven spatiotemporal distribution of water resources has led to water shortages that limit maize yield in arid and semiarid areas ${ }^{9}$.

Water stress is one of the most vital environmental stresses that generally results in decreased growth and final yield in many crops ${ }^{10-12}$. The vegetative growth stage is inhibited by water stress and results in decreased overall growth, leaf area, and yield in maize plants ${ }^{13}$. When the soil water content is suboptimal during the vegetative growth and grain-filling stages, high maize yield can be obtained through full irrigation at the flowering stage ${ }^{14}$. Maize exposed to light water stress throughout the early growth and late grain-filling stages exhibited some water stress tolerance due to the low water demand of these stages ${ }^{15}$. Maximizing crop productivity by utilizing

\footnotetext{
${ }^{1}$ Plant Production Department, Faculty of Agriculture, Saba Basha, Alexandria University, Alexandria 21531, Egypt. ${ }^{2}$ Agriculture Research Center (ARC), Etay El-Baroud Research Station, El-Beheira, Egypt. ${ }^{3}$ Botany and Microbiology Department, College of Science, King Saud University, P.O. Box 2455, Riyadh 11451, Saudi Arabia. ${ }^{4}$ Timber Trees Research Department, Sabahia Horticulture Research Station, Horticulture Research Institute, Agriculture Research Center, Alexandria 21526, Egypt. ${ }^{5}$ Agricultural Botany Department, Faculty of Agriculture (Saba Basha), Alexandria University, Alexandria 21531, Egypt. ${ }^{\circledR}$ email: essam.kandil@alexu.edu.eg
} 
accessible irrigation is a global sustainable goal and the center of much research because agriculture is the core consumer of freshwater ${ }^{16,17}$.

Silicon ( $\mathrm{Si}$ ) is an important nutrient for high-yielding crop species such as cereals, legumes, and vegetables. $\mathrm{Si}$ can be detected in limiting levels under some growing conditions, and without Si, plants may suffer subtle nutrient deficiency. Si deficiency decreased photosynthesis, lowered Brix, increased disease prevalence and insect attacks, increased wilting, and enhanced postharvest fall. All these symptoms are signs of stress ${ }^{18,19}$. In addition, Si aids in healthy plant development and is essential for cell development and differentiation ${ }^{20}$. Si treatment can alleviate drought stress, salt stress, heat stress, and oxidative damage. The beneficial role of Si in drought conditions is mainly due to enhanced water retention aiding photosynthesis ${ }^{21-25}$. Potassium silicate (K-silicate) is a source of highly soluble $\mathrm{K}$ and $\mathrm{Si}$. K-silicate encloses no volatile organic compounds, and application does not result in the release of hazardous or environmentally persistent by-products ${ }^{26}$. K-silicate application to the soil of some cereal species under water-deficit irrigation produced the highest biomass yield responses across species. Si may work as a growth regulator and has the potential to increase plant growth under drought stress ${ }^{27}$. The growth and yield of maize were highly responsive to $\mathrm{Si}$ application under stressed conditions $\mathrm{s}^{5,28}$. Spraying $\mathrm{K}$-silicate and other nanomaterials has the potential to reduce the harmful effects of drought stress on crops $\mathrm{s}^{29-32}$.

Silicon was revealed to be helpful to plants by reducing the absorption of high levels of nutrients, which may be present in soil, in plant tissue and by preventing tissue damage ${ }^{33}$. Si has a role in ethylene inhibition, which decreases the speed of aging and death of harvested plant parts. Si is beneficial for chlorophyll content and helps crops maintain freshness longer with better appearance. Thus, Si has a positive impact on both crop yield and quantity $^{34}$. The grain yield of rice was improved with the application of Si fertilizer ${ }^{35}$. Also ${ }^{12}$, revealed that spraying of nanoparticles of $\mathrm{SiO}_{2}$, improved the growth and yield parameters of strawberry plants under water stress.

Here, we investigate irrigation intervals to achieve the highest productivity and water use efficiency (WUE). We also evaluate the performance of K-silicate foliar spray to mitigate water-deficit stress on maize yield and examine its effect on WUE.

\section{Materials and methods}

Experimental site. Two field experiments were conducted at the Experimental Farm of Etay El-Baroud Station, El-Beheira Governorate, Agriculture Research Center (ARC), Egypt, during the 2017 and 2018 growing

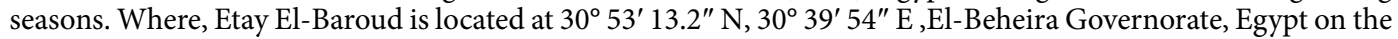
agricultural road between Cairo and Alexandria, north of Kafr El Zayat and south of Damanhour, and is $140 \mathrm{~km}$ away from Cairo and $84 \mathrm{~km}$ from Alexandria (Table 1). The experiments were carried out to study the effect of irrigation intervals, foliar application of Si and their interaction on maize productivity in 2017 and 2018 seasons.

Soil samples of the experimental area were air-dried, passed through a two $\mathrm{mm}$ sieve, and examined according to the procedures described by ${ }^{36}$. The dominant soil type of the experimental site was loamy clay $(60.7 \%)$ with $\mathrm{pH}$ 8.0, organic matter (3.0\%), HCO-3 (0.8 meq/l), CL- (8.8 meq/l), Ca ${ }^{++}(6.1 \mathrm{meq} / \mathrm{l}), \mathrm{Mg}^{+}(3.5 \mathrm{meq} / \mathrm{l})$, and $\mathrm{K}+(1.5 \mathrm{meq} / \mathrm{l})$ average over the two seasons.

Experimentation, factors, and their levels. A split-plot design with four replicates was used in both seasons. The main plot was used to investigate irrigation intervals. The irrigation intervals treatments were as follows: (1) Irrigation every 10 days (I1); (2) Irrigation every 15 days (I2) and, (3) Irrigation every 20 days (I3). The subplots were treated with K-silicate treatments as follows: (1) Spray once at 40 days after sowing (S1); (2) Spray twice at 40 and 60 days after sowing, respectively (S2) and, (3) Spray three times at 40, 60, and 80 day after sowing, respectively (S3) and, (4) Control (water spray) (S4).

The liquid K-silicate $\left(\mathrm{K}_{2} \mathrm{SiO}_{3} ; 10 \% \mathrm{~K}_{2} \mathrm{O}, 25 \% \mathrm{SiO}_{2}\right)$ was obtained from Abo Ghaneima Company Trade and Agencies, Alexandria-Abu Qir and applied at the rate of $1000 \mathrm{~cm}^{3} / 1$. Yellow maize hybrid (SC168) was sown on June 3 and May 28 in 2017 and 2018, respectively. Maize was sown in hill spaced $25 \mathrm{~cm}$, and plants were thinned to one plant per hill. Calcium superphosphate (12.5\%) was added at the rate of $60 \mathrm{~kg} \mathrm{P}_{2} \mathrm{O}_{5} / \mathrm{ha}$ (ha $=2.4$ feddan) during soil preparation. Nitrogen fertilizer from urea $(46.5 \% \mathrm{~N})$ was added at the rate of $288 \mathrm{~kg} \mathrm{~N} / \mathrm{ha}$ in two equal doses before the 1 st and second irrigations.

Each sub plot consisted of 5 ridges $6 \mathrm{~m}$ in length and $70 \mathrm{~cm}$ in the width and plot area was 21 (square meter $=\mathrm{m}^{2}$ ) and the treatments were distributed randomized in 4 replicates. All the agricultural practice was done according the recommendation of Ministry of Agriculture and Land Reclamation.

Data recording. During current study, at harvest time, the ears were harvested from the two middle ridges of each sub plot to determine the following characters i.e., the plant height $(\mathrm{cm})$, ear length \& diameter $(\mathrm{cm})$, grain weight/ear $(\mathrm{g})$, shelling percentage $(\%), 100$-grain weight $(\mathrm{g})$, biological, grain and straw yield $(\mathrm{t} / \mathrm{ha})$ were estimated. The shelling $\%$ for each treatment was determined using the following formula ${ }^{37}$ :

$$
\text { Shelling percentage }=\frac{\text { Grain weight of ears }}{\text { Total weight of ears }} \times 100
$$

WUE was calculated according the method described by Israelsen and Hansen ${ }^{37}$ as follows:

$$
W U E=\frac{\text { Grain yield }(\mathrm{kg} / \mathrm{area})}{\text { Total } \text { water } \text { used }\left(\mathrm{m}^{3} / \mathrm{area}\right)} \times 100
$$

Grain protein percentage (\%) was determined according to the improved Kjeldahl method, where approximately $1 \mathrm{~g}$ of grains of maize was hydrolyzed with $15 \mathrm{~mL}$ concentrated sulfuric acid $\left(\mathrm{H}_{2} \mathrm{SO}_{4}\right)$ containing two copper catalyst tablets in a heat block at $420^{\circ} \mathrm{C}$ for $2 \mathrm{~h}$. After cooling, $\mathrm{H}_{2} \mathrm{O}$ was added to the hydrolysates before 


\begin{tabular}{|c|c|c|c|c|c|c|}
\hline \multirow[b]{4}{*}{ Month } & \multicolumn{4}{|c|}{ HC air temperature (C0) } & \multirow{3}{*}{\multicolumn{2}{|c|}{$\begin{array}{l}\text { HC relative } \\
\text { humidity (\%) }\end{array}$}} \\
\hline & \multicolumn{4}{|c|}{ Seasons } & & \\
\hline & 2017 & 2018 & 2017 & 2018 & & \\
\hline & \multicolumn{2}{|c|}{ Minimum } & \multicolumn{2}{|c|}{ Maximum } & 2017 & 2018 \\
\hline May & 17.1 & 22.0 & 38.0 & 40.9 & 65.0 & 62.1 \\
\hline June & 20.5 & 20.3 & 40.2 & 40.8 & 73.0 & 71.8 \\
\hline July & 19.1 & 20.5 & 37.3 & 35.9 & 74.8 & 79.0 \\
\hline August & 17.4 & 20.0 & 36.7 & 35.4 & 72.2 & 77.3 \\
\hline September & 17.0 & 19.0 & 35.7 & 32.4 & 68.5 & 73.2 \\
\hline
\end{tabular}

Table 1. Meteorological of the experimental site in both seasons. Source: Central Laboratory for Agriculture Climate, the Agriculture Research Center, Egypt.

neutralization and titration. The amount of total nitrogen in the grains were multiplied with the traditional conversion factor of $6.25^{38}$ in order to determine total protein content.

Grain oil percentage (\%) was determined by extraction using a Soxhlet apparatus according to the methods described by the Association of Official Agricultural Chemists ${ }^{39}$, where maize grains were crushed and ground into a fine powder. The oil was extracted from each seed sample $(30.0 \mathrm{~g})$ with $\mathrm{n}$-hexane $(250 \mathrm{~mL})$ using a Soxhlet extractor at $70^{\circ} \mathrm{C}$ for $6 \mathrm{~h}$. After extraction, the hexane-oil mixture was passed through a layer of anhydrous magnesium sulfate placed over filter paper in a funnel. The solvent was evaporated under vacuum using a rotary evaporator at $40^{\circ} \mathrm{C}$. The resultant oil was weighed and flushed with nitrogen and stored at $-20{ }^{\circ} \mathrm{C}$ until further analysis.

Statistical analysis. We subjected all the parameters to analysis of variance and further statistically analyzed according to ${ }^{40}$ for split-plot arrangement. Also, the means between different treatments were compared using (LSD) a least significant differences test $(\mathrm{p} \leq 0.05)$ in the CoStat software package ${ }^{41}$.

Human and animal rights. This article does not contain any studies with human or animal subjects.

\section{Results}

Maize response to irrigation intervals (I). Table 2 shows the significant effect of irrigation intervals on plant height $(\mathrm{cm})$, ear length $(\mathrm{cm})$, grain weight $(\mathrm{g}) /$ ear, and shelling percentage $(\%)$, but not ear diameter $(\mathrm{cm})$, of maize during the 2017 and 2018 seasons. The tallest plant height was recorded with irrigation every 10 days in both seasons, whereas the longest ear length was obtained with irrigation each 10 and 15 days in first and second seasons, respectively. The heaviest grain weight was achieved with irrigation every 15 days in both seasons. Irrigation every 10 and 15 days recorded the highest values of shelling percentage in the first and second seasons, respectively. The lowest growth responses occurred with irrigation each 20 days in the two experiment years.

Results given in Table 3 indicate that irrigation intervals significantly affected 100-grain weight, biological yield $(\mathrm{t} / \mathrm{ha})$, grain yield $(\mathrm{t} / \mathrm{ha})$, straw yield $(\mathrm{t} / \mathrm{ha})$, and WUE in the two studied seasons. The highest 100-grain weight values were recorded with irrigation every 10 days. However, there was no significant difference among irrigation each 15 days, which gave the highest mean values of biological yield, grain yield, and straw yield per ha. Irrigation every 20 days resulted in the lowest values of these traits but achieved the highest WUE. Irrigation each 10-day interval recorded the lowest WUE values in both seasons.

The irrigation every 10 days increased 100-grain weight by 14.29 and $16.67 \%$ as compared with interval irrigation 20 days in the first and the second seasons, respectively. While irrigation every 15 days increased biological yield by 12.17 and $10.13 \%$, straw yield by 13.38 and $11.97 \%$, as compared with interval irrigation 20 days in the first and the second seasons, respectively. On the other hand, grain yield increased by 10.23 and $11.49 \%$ with irrigation every 15 and 10 days as compared with interval irrigation 20 days in the first and the second seasons, respectively.

Table 4 shows the effect of irrigation intervals on grain protein and oil content, where irrigated maize plants every 15 days (I2) recorded the highest mean values of grain protein content (\%), on the other hand, irrigation interval (10 days) gave the highest value of oil content in grain in the two seasons.

Maize response to K-silicate (S). Table 2 shows the significant effect of foliar usage of K-silicate on plant height, ear length, ear diameter, grain weight, and shelling percentage of maize during the 2017 and 2018 seasons. The tallest plant height, longest ear length, largest ear diameter, and heaviest grain weight were recorded with three foliar applications of K-silicate. The lowest yield parameters were recorded with water spray (control $=$ S4) treatments in both seasons.

Results in Table 3 revealed that K-silicate had significant effects on 100-grain weight, biological yield/ha, grain yield/ha, straw yield/ha, and WUE in both seasons. As compared with other treatments, the highest values occurred when maize plants were sprayed K-silicate three times (S3), whereas the lowest values occurred with foliar water spray (control $=$ S4) treatments in 2017 and 2018 seasons. 100-grain weight increased with increasing K-silicate spraying three times by 17.01 and $15.52 \%$, biological yield increased by 15.74 and $10.78 \%$, straw 


\begin{tabular}{|c|c|c|c|c|c|c|c|c|c|c|c|c|c|c|c|c|c|}
\hline \multirow[b]{3}{*}{ Characters } & \multirow[b]{3}{*}{$\begin{array}{l}\text { Irrigation } \\
\text { intervals } \\
\text { (I) }\end{array}$} & \multicolumn{8}{|c|}{ Season 2017} & \multicolumn{8}{|c|}{ Season 2018} \\
\hline & & \multicolumn{5}{|c|}{ Foliar application of $\mathrm{K}$-silicate $\left(\mathrm{K}_{2} \mathrm{SiO}_{3}\right)$} & \multicolumn{3}{|c|}{ L.S.D. ${ }_{0.05}$} & \multicolumn{5}{|c|}{ Foliar application of $\mathrm{K}$-silicate $\left(\mathrm{K}_{2} \mathrm{SiO}_{3}\right)$} & \multicolumn{3}{|c|}{ L.S.D..$_{0.05}$} \\
\hline & & $\begin{array}{l}\text { S1 } \\
\text { (once) }\end{array}$ & $\begin{array}{l}\text { S2 } \\
\text { (twice) }\end{array}$ & \begin{tabular}{|l} 
S3 \\
(three \\
times)
\end{tabular} & $\begin{array}{l}\text { S4 } \\
\text { (control) }\end{array}$ & $\begin{array}{l}\text { Average } \\
\text { (I) }\end{array}$ & I & S & $\mathrm{I} \times \mathrm{S}$ & $\begin{array}{l}\text { S1 } \\
\text { (once) }\end{array}$ & $\begin{array}{l}\text { S2 } \\
\text { (twice) }\end{array}$ & \begin{tabular}{|l} 
S3 \\
(three \\
times)
\end{tabular} & $\begin{array}{l}\text { S4 } \\
\text { (control) }\end{array}$ & $\begin{array}{l}\text { Average } \\
\text { (I) }\end{array}$ & I & S & $\mathrm{I} \times \mathrm{S}$ \\
\hline \multirow{4}{*}{$\begin{array}{l}\text { Plant height } \\
(\mathrm{cm})\end{array}$} & $\begin{array}{l}\text { I1 } \\
\text { (10 days })\end{array}$ & 251.7 & 245.7 & 254.7 & 251.3 & 250.8 & & & & 236.0 & 220.0 & 220.0 & 231.0 & 226.8 & & & \\
\hline & \begin{tabular}{|l|} 
I2 \\
(15 days $)$ \\
\end{tabular} & 227.0 & 239.3 & 248.3 & 226.7 & 235.3 & 6.7 & 5.4 & 9.3 & 219.0 & 211.3 & 224.7 & 208.7 & 215.9 & 6.9 & 5.0 & 10.3 \\
\hline & \begin{tabular}{|l|} 
I3 \\
(20 days)
\end{tabular} & 229.5 & 238.3 & 251.3 & 223.7 & 235.7 & & & & 200.0 & 198.7 & 205.3 & 194 & 199.5 & & & \\
\hline & Average & 236.1 & 241.1 & 251.4 & 233.9 & & & & & 218.3 & 210.0 & 216.7 & 211.2 & & & & \\
\hline \multirow{4}{*}{$\begin{array}{l}\text { Ear length } \\
(\mathrm{cm})\end{array}$} & $\begin{array}{l}\text { I1 } \\
\text { (10 days) }\end{array}$ & 18.53 & 19.07 & 20.4 & 18.8 & 19.2 & & & & 17.2 & 18.3 & 18.6 & 18.8 & 18.2 & & & \\
\hline & \begin{tabular}{|l|} 
I2 \\
(15 days $)$
\end{tabular} & 18.2 & 18.27 & 20.3 & 18.4 & 18.8 & 0.4 & 1.0 & 1.1 & 18.8 & 19.3 & 19.5 & 18.9 & 19.1 & 0.6 & 0.9 & 1.2 \\
\hline & \begin{tabular}{|l|} 
I3 \\
(20 days)
\end{tabular} & 17.33 & 17.9 & 18.9 & 17.5 & 17.9 & & & & 18.2 & 18.5 & 19.67 & 17.4 & 18.4 & & & \\
\hline & Average & 18.0 & 18.4 & 19.9 & 18.2 & & & & & 18.1 & 18.7 & 19.3 & 18.4 & & & & \\
\hline \multirow{4}{*}{$\begin{array}{l}\text { Ear diam- } \\
\text { eter }(\mathrm{cm})\end{array}$} & $\begin{array}{l}\text { I1 } \\
\text { (10 days) }\end{array}$ & 4.3 & 4.5 & 4.6 & 4.3 & 4.4 & & & & 4.3 & 4.4 & 4.5 & 4.5 & 4.4 & & & \\
\hline & \begin{tabular}{|l|} 
I2 \\
(15 days $)$
\end{tabular} & 4.2 & 4.5 & 4.6 & 4.4 & 4.4 & ns & 0.3 & ns & 4.3 & 4.4 & 4.5 & 4.2 & 4.3 & ns & ns & ns \\
\hline & \begin{tabular}{|l|} 
I3 \\
(20 days)
\end{tabular} & 4.2 & 4.3 & 4.5 & 4.0 & 4.3 & & & & 4.3 & 4.5 & 4.5 & 4.3 & 4.4 & & & \\
\hline & Average & 4.2 & 4.4 & 4.6 & 4.2 & & & & & 4.3 & 4.4 & 4.5 & 4.4 & & & & \\
\hline \multirow{4}{*}{$\begin{array}{l}\text { Grain } \\
\text { weight/ear } \\
\text { (g) }\end{array}$} & $\begin{array}{l}\text { I1 } \\
\text { (10 days) }\end{array}$ & 149.9 & 171.2 & 171.9 & 154.2 & 161.8 & & & & 150.5 & 168.7 & 177.1 & 151.5 & 162.0 & & & \\
\hline & \begin{tabular}{|l|} 
I2 \\
(15 days $)$
\end{tabular} & 157.7 & $\mid 170.1$ & 177.1 & $\mid 154.0$ & 164.7 & 15.0 & 13.0 & 19.8 & 158.8 & 169.1 & 176.7 & 155.8 & $\mid 165.1$ & 6.9 & 6.5 & 12.5 \\
\hline & \begin{tabular}{|l|} 
I3 \\
(20 days)
\end{tabular} & 130.8 & $\mid 153.8$ & 167.3 & $\mid 133.3$ & 146.3 & & & & 134.0 & 153.8 & 166.5 & 136.8 & 147.8 & & & \\
\hline & Average & \begin{tabular}{|l|}
146.1 \\
\end{tabular} & 165.0 & 172.1 & \begin{tabular}{|l|}
147.2 \\
\end{tabular} & & & & & \begin{tabular}{|l|}
147.8 \\
\end{tabular} & 163.9 & \begin{tabular}{|l|}
173.4 \\
\end{tabular} & \begin{tabular}{|l|l|}
148.0 \\
\end{tabular} & & & & \\
\hline \multirow{4}{*}{$\begin{array}{l}\text { Shelling } \\
\text { percentage } \\
(\%)\end{array}$} & $\begin{array}{l}\text { I1 } \\
\text { (10 days) }\end{array}$ & 77.0 & 75.0 & 80.0 & 76.0 & 77.0 & & & & 83.0 & 89.0 & 90.0 & 81.0 & 85.8 & & & \\
\hline & \begin{tabular}{|l|} 
I2 \\
(15 days $)$
\end{tabular} & 74.0 & 78.0 & 81.0 & 74.0 & 76.8 & 1.5 & 3.5 & 4.3 & 86.0 & 87.0 & 91.0 & 82.0 & 86.5 & 2.6 & 4.1 & 5.8 \\
\hline & \begin{tabular}{|l|} 
I3 \\
(20 days)
\end{tabular} & 70.0 & 72.0 & 75.0 & 69.0 & 71.5 & & & & 77.0 & 81.0 & 85.0 & 73.0 & 79.0 & & & \\
\hline & Average & 73.7 & 75.0 & 78.7 & 73.0 & & & & & 82.0 & 85.7 & 88.7 & 78.7 & & & & \\
\hline
\end{tabular}

Table 2. Plant height, ear length, ear diameter, grain weight/ear, and shelling percentage of maize as affected by irrigation intervals and foliar application of K-silicates in the 2017 and 2018 seasons. I1, I2, and I3: irrigation intervals treatments; S1,S2, S3 and S4: foliar application of K-silicate treatments; ns, not significant; L.S.D.at $5 \%$, the least significant difference at a $5 \%$ level of significance.

yield increased by 18.06 and $7.09 \%$, grain yield increased by 12.09 and $17.58 \%$ and water use efficiency (WUE) increased by 17.65 and 18.75 as compared with the control treatments (spray water) in the first and the second seasons, respectively.

Table 4 shows significant differences between foliar spray treatment and control on grain protein and oil contents in both seasons. Foliar spraying with K-silicate three times (S3) recorded the highest values of these measures.

Maize response to interaction between irrigation intervals and K-silicate $(I \times S)$. The interaction results among irrigation intervals and foliar spray with K-silicate had major effect on plant height, ear length, grain weight, and shelling percentage, but not ear diameter, in both the 2017 and 2018 seasons (Table 2). The greatest values of these traits were recorded when maize plants were irrigated every 15 days (I2) under foliar spraying with K-silicate three times (S3), whereas the lowest values resulted from irrigation every 10 or 20 days under water spray (control) in both cropping seasons.

The interaction values between irrigation intervals and foliar spray with K-silicate had considerable effect on 100 -grain weight, biological yield, grain yield, straw yield, and WUE in both seasons (Table 3). The maximum values of these traits were recorded when maize plants were irrigated every 15 days (I2) under foliar spraying with K-silicate three times (S3) in both seasons, whereas the lowest ones were given with irrigation every 10 or 20 days under water spray (control) in both cropping seasons. WUE provides information on the adaptation potential of a plant to water stress conditions, making it an important characteristic. WUE under irrigation every 20 days (I3) interval and foliar spraying with $\mathrm{K}$-silicate three times (S3) gave the highest values, followed by irrigation interval (I2), under the same foliar spray (S3) in 2017 and 2018 seasons. Foliar spraying of water 


\begin{tabular}{|c|c|c|c|c|c|c|c|c|c|c|c|c|c|c|c|c|c|}
\hline \multicolumn{2}{|l|}{ Treatments } & \multicolumn{8}{|l|}{2017} & \multicolumn{8}{|l|}{2018} \\
\hline \multirow[b]{2}{*}{ Characters } & \multirow[b]{2}{*}{$\begin{array}{l}\text { Irrigation } \\
\text { intervals } \\
\text { (I) }\end{array}$} & \multicolumn{5}{|c|}{ Foliar application of $\mathrm{K}$-silicate $\left(\mathrm{K}_{2} \mathrm{SiO}_{3}\right)$} & \multicolumn{3}{|c|}{ L.S.D. .0 .05} & \multicolumn{5}{|c|}{ Foliar application of $\mathrm{K}$-silicate $\left(\mathrm{K}_{2} \mathrm{SiO}_{3}\right)$} & \multicolumn{3}{|c|}{ L.S.D. 0.05} \\
\hline & & \begin{tabular}{|l} 
S1 \\
(once)
\end{tabular} & $\begin{array}{l}\text { S2 } \\
\text { (twice) }\end{array}$ & \begin{tabular}{|l|} 
S3 \\
(three \\
times)
\end{tabular} & \begin{tabular}{|l} 
S4 \\
(control)
\end{tabular} & $\begin{array}{l}\text { Average } \\
\text { (I) }\end{array}$ & I & S & $I \times S$ & \begin{tabular}{|l} 
S1 \\
(once)
\end{tabular} & $\begin{array}{l}\text { S2 } \\
\text { (twice) }\end{array}$ & $\begin{array}{l}\text { S3 } \\
\text { (three } \\
\text { times) }\end{array}$ & $\begin{array}{l}\text { S4 } \\
\text { (control) }\end{array}$ & $\begin{array}{l}\text { Average } \\
\text { (I) }\end{array}$ & I & S & $\mathbf{I} \times \mathbf{S}$ \\
\hline \multirow{4}{*}{$\begin{array}{l}\text { 100-grain } \\
\text { weight }(\mathrm{g})\end{array}$} & $\begin{array}{l}\text { I1 } \\
\text { (10 days })\end{array}$ & 26.6 & 28.2 & 30.6 & 26.5 & 28.0 & & & & 26.9 & 28.6 & 30.1 & 27.2 & 28.2 & & & \\
\hline & $\begin{array}{l}\text { I2 } \\
\text { (15 days })\end{array}$ & 27.1 & 28.1 & 29.7 & 25.4 & 27.6 & 1.3 & 1.6 & 2.0 & 26.1 & 28.2 & 29.8 & 25.9 & 27.5 & 1.3 & 1.5 & 2.5 \\
\hline & $\begin{array}{l}\text { I3 } \\
\text { (20 days) }\end{array}$ & 21.9 & 25.0 & 27.9 & 21.3 & 24.0 & & & & 22.3 & 24.3 & 27.1 & 20.5 & 23.5 & & & \\
\hline & Average & 25.2 & 27.1 & 29.4 & 24.4 & & & & & 25.1 & 27.0 & 29.0 & 24.5 & & & & \\
\hline \multirow{4}{*}{$\begin{array}{l}\text { Biological } \\
\text { yield (t/ha) }\end{array}$} & $\begin{array}{l}\text { I1 } \\
(10 \text { days })\end{array}$ & 20.4 & 22.1 & 23.3 & 19.7 & 21.4 & & & & 21.8 & 22.6 & 23.5 & 21.6 & 22.4 & & & \\
\hline & \begin{tabular}{|l}
$\mathrm{I} 2$ \\
(15 days)
\end{tabular} & 22.6 & 23.5 & 25.2 & 20.6 & 23.0 & 0.7 & 1.2 & 1.7 & 22.3 & 22.8 & 23.8 & 21.8 & 22.7 & 0.2 & 0.7 & 1.4 \\
\hline & $\begin{array}{l}\text { I3 } \\
(20 \text { days })\end{array}$ & 19.4 & 20.4 & 22.1 & 19.0 & 20.2 & & & & 19.4 & 21.1 & 22.3 & 18.7 & 20.4 & & & \\
\hline & Average & 20.8 & 22.0 & 23.5 & 19.8 & & & & & 21.2 & 22.2 & 23.2 & 20.7 & & & & \\
\hline \multirow{4}{*}{$\begin{array}{l}\text { Straw yield } \\
(\mathrm{t} / \mathrm{ha})\end{array}$} & $\begin{array}{l}\text { I1 } \\
\text { (10 days })\end{array}$ & 12.2 & 13.4 & 14.2 & 11.8 & 12.9 & & & & 13.4 & 13.9 & 14.2 & 13.2 & 13.7 & & & \\
\hline & $\begin{array}{l}\text { I2 } \\
\text { (15 days })\end{array}$ & 13.9 & 14.6 & 15.6 & 12.7 & 14.2 & 1.2 & 1.3 & 2.1 & 13.9 & 14.2 & 14.4 & 14.4 & 14.2 & 0.5 & 0.7 & 1.4 \\
\hline & $\begin{array}{l}\text { I3 } \\
\text { (20 days })\end{array}$ & 12.2 & 12.7 & 13.4 & 10.8 & 12.3 & & & & 12.0 & 13.2 & 13.7 & 12.0 & 12.7 & & & \\
\hline & Average & 12.8 & 13.6 & 14.4 & 11.8 & & & & & 13.1 & 13.8 & 14.1 & 13.1 & & & & \\
\hline \multirow{4}{*}{$\begin{array}{l}\text { Grain yield } \\
(\mathrm{t} / \mathrm{ha})\end{array}$} & $\begin{array}{l}\text { I1 } \\
\text { (10 days })\end{array}$ & 8.2 & 8.6 & 9.1 & 7.9 & 8.5 & & & & 8.4 & 8.6 & 9.4 & 8.4 & 8.7 & & & \\
\hline & $\begin{array}{l}\mathrm{I} 2 \\
\text { (15 days) }\end{array}$ & 8.6 & 8.9 & 9.6 & 7.9 & 8.8 & 0.6 & 0.1 & 0.7 & 8.4 & 8.6 & 9.4 & 7.4 & 8.5 & 0.7 & 0.6 & 0.9 \\
\hline & \begin{tabular}{|l} 
I3 \\
(20 days $)$
\end{tabular} & 7.2 & 7.7 & 8.6 & 8.2 & 7.9 & & & & 7.4 & 7.9 & 8.6 & 6.7 & 7.7 & & & \\
\hline & Average & 8.0 & 8.4 & 9.1 & 8.0 & & & & & 8.1 & 8.4 & 9.1 & 7.5 & & & & \\
\hline \multirow{4}{*}{$\begin{array}{l}\text { Water use } \\
\text { efficiency } \\
(\text { WUE) (kg/ } \\
\left.\mathrm{m}^{3}\right)\end{array}$} & $\begin{array}{l}\text { I1 } \\
(10 \text { days })\end{array}$ & 1.1 & 1.2 & 1.3 & 1.0 & 1.2 & & & & 1.1 & 1.1 & 1.2 & 1.0 & 1.1 & & & \\
\hline & $\begin{array}{l}\mathrm{I} 2 \\
\text { (15 days) }\end{array}$ & 1.5 & 1.6 & 1.8 & 1.5 & 1.6 & 0.2 & 0.1 & 0.2 & 1.4 & 1.4 & 1.8 & 1.3 & 1.5 & 0.1 & 0.1 & 0.1 \\
\hline & $\begin{array}{l}\text { I3 } \\
\text { (20 days })\end{array}$ & 1.8 & 1.8 & 2.1 & 1.6 & 1.8 & & & & 1.4 & 1.6 & 1.9 & 1.5 & 1.6 & & & \\
\hline & Average & 1.5 & 1.5 & 1.7 & 1.4 & & & & & 1.3 & 1.4 & 1.6 & 1.3 & & & & \\
\hline
\end{tabular}

Table 3. Yield and yield components of maize as affected by irrigation intervals and foliar application of K-silicates in the 2017 and 2018 seasons. I1, I2, and I3: irrigation intervals treatments; S1,S2, S3 and S4: foliar application of K-silicate treatments; L.S.D.at 5\%, the least significant difference at a 5\% level of significance.

(S4) recorded the lowest values under irrigation each 10 days (I1) in both seasons (see Table 3). The interaction of irrigation and Si treatment had a significant effect on protein content in both seasons. Treatment S3 recorded the highest values, whereas irrigation every 15 days (I3) and water spray control treatments (S4) gave the lowest values in both seasons. The interaction had significant effect on grain oil content. Foliar spraying with K-silicate three times (S3) recorded the highest values. Irrigation every 15 days (I3) combined with water spray control treatments (S4) gave the lowest values in both seasons (Table 4).

\section{Discussion}

These results support those obtained $b^{42}$, who reported that water stress significantly decreased growth, grain yield, and water characteristics as WUE. Also ${ }^{29}$, found that increasing the irrigation interval from 8 to 14 and 20 days caused a significant decrease in growth and yield of the crop. Shi et al. ${ }^{43}$ showed WUE was higher in the dry-cultivation treatment since yields decreased relatively less than the supply of irrigation water. However, higher WUE can be achieved by relating deficit stress at the late vegetative stage somewhat than maturation stage $^{44}$.

The reduction of yield, yield component and quality under waters stress could be due to numerous reasons including decrease of photosynthesis efficiency, leaf area, net assimilation production, and reduction of water and mineral absorption by the root which ultimately decline developmental and vegetative growth ${ }^{11}$.

The results indicate that increasing irrigation intervals to 20 day reduced all the studied characteristics likely due to water stress deficit. Inadequate available soil water reduces the metabolic activity of maize, decreases its dry matter accumulation, and reduces its photosynthetic level by reducing the chlorophyll content in leaves. These changes eventually lead to a loss in maize yield ${ }^{45}$. Further, water stress had a greater effect on the growth and development of maize through the seedling stage than the other three stages. Water stress reduced growth 


\begin{tabular}{|c|c|c|c|c|c|c|c|c|c|c|c|c|c|c|c|c|c|}
\hline \multicolumn{2}{|l|}{ Treatments } & \multicolumn{8}{|l|}{2017} & \multicolumn{8}{|l|}{2018} \\
\hline \multirow[b]{2}{*}{ Characters } & \multirow[b]{2}{*}{$\begin{array}{l}\text { Irrigation } \\
\text { intervals } \\
\text { (I) }\end{array}$} & \multicolumn{5}{|c|}{ Foliar application of K-silicate $\left(\mathrm{K}_{2} \mathrm{SiO}_{3}\right)$} & \multicolumn{3}{|c|}{ L.S.D. ${ }_{0.05}$} & \multicolumn{5}{|c|}{ Foliar application of $\mathrm{K}$-silicate $\left(\mathrm{K}_{2} \mathrm{SiO}_{3}\right)$} & \multicolumn{3}{|c|}{ L.S.D. .0 .05} \\
\hline & & $\begin{array}{l}\text { S1 } \\
\text { (once) }\end{array}$ & $\begin{array}{l}\text { S2 } \\
\text { (twice) }\end{array}$ & $\begin{array}{l}\text { S3 } \\
\text { (three } \\
\text { times) }\end{array}$ & $\begin{array}{l}\text { S4 } \\
\text { (control) }\end{array}$ & $\begin{array}{l}\text { Average } \\
\text { (I) }\end{array}$ & I & S & $\mathbf{I} \times \mathbf{S}$ & $\begin{array}{l}\text { S1 } \\
\text { (once) }\end{array}$ & $\begin{array}{l}\text { S2 } \\
\text { (twice) }\end{array}$ & $\begin{array}{l}\text { S3 } \\
\text { (three } \\
\text { times) }\end{array}$ & $\begin{array}{l}\text { S4 } \\
\text { (control) }\end{array}$ & $\begin{array}{l}\text { Average } \\
\text { (I) }\end{array}$ & I & $S$ & $\mathrm{I} \times \mathrm{S}$ \\
\hline \multirow{4}{*}{$\begin{array}{l}\text { Grain pro- } \\
\text { tein content } \\
(\%)\end{array}$} & $\begin{array}{l}\text { I1 } \\
\text { (10 days) }\end{array}$ & 9.2 & 9.7 & 9.9 & 8.9 & 9.4 & & & & 9.4 & 9.8 & 10.0 & 9.0 & 9.5 & & & \\
\hline & $\begin{array}{l}\text { I2 } \\
\text { (15 days) }\end{array}$ & 9.6 & 9.8 & 11.0 & 10.0 & 10.1 & 0.5 & 0.7 & 1.1 & 10.1 & 10.5 & 11.2 & 9.2 & 10.2 & 0.4 & 0.6 & 1.0 \\
\hline & $\begin{array}{l}\text { I3 } \\
\text { (20 days) }\end{array}$ & 9.7 & 10.2 & 10.4 & 8.9 & 9.8 & & & & 10.0 & 10.1 & 10.1 & 8.8 & 9.8 & & & \\
\hline & Average & 9.5 & 9.9 & 10.5 & 9.3 & & & & & 9.8 & 10.1 & 10.4 & 9.0 & & & & \\
\hline \multirow{4}{*}{$\begin{array}{l}\text { Grain oil } \\
\text { content (\%) }\end{array}$} & $\begin{array}{l}\text { I1 } \\
\text { (10 days) }\end{array}$ & 3.6 & 3.6 & 3.9 & 3.3 & 3.6 & & & & 3.6 & 3.6 & 3.9 & 3.4 & 3.6 & & & \\
\hline & $\begin{array}{l}\text { I2 } \\
\text { (15 days) }\end{array}$ & 3.4 & 3.5 & 3.7 & 3.4 & 3.5 & 0.3 & 0.4 & 0.5 & 3.4 & 3.6 & 3.8 & 3.5 & 3.6 & 0.3 & 0.3 & 0.6 \\
\hline & $\begin{array}{l}\text { I3 } \\
\text { (20 days) }\end{array}$ & 3.3 & 3.3 & 3.2 & 3.2 & 3.3 & & & & 3.3 & 3.2 & 3.3 & 3.3 & 3.3 & & & \\
\hline & Average & 3.4 & 3.5 & 3.6 & 3.3 & & & & & 3.5 & 3.5 & 3.7 & 3.4 & & & & \\
\hline
\end{tabular}

Table 4. Grain protein content (\%) and content oil (\%) of maize as affected by irrigation intervals and foliar application of K-silicates in the 2017 and 2018 seasons. I1, I2, and I3: irrigation intervals treatments; S1,S2, S3 and S4: foliar application of K-silicate treatments; L.S.D.at 5\%, the least significant difference at a 5\% level of significance.

and biomass due to decreased intercepted photosynthetically active radiation and radiation-use efficiency. These effects extended into the reproductive stage and finally decreased grain weight and yield ${ }^{45}$. Water deficit stress through the later vegetative and maturation stage directly decreased the grain-filling level and period and thus had the greatest effect on grain yield and its components. Yield was reduced after water-deficit stress occurred during the late vegetative stage and was exacerbated by additional stress during the maturation stage. In all treatments, yield decrease was proportional to the severity of the water stress. However, water stress used had a larger effect on maize yield during the maturation stage than during the late vegetative stage ${ }^{46}$.

These findings support previous investigations by ${ }^{47}$ who showed that weekly K-silicate foliar spraying resulted in a significant effect on growth and yield parameters of maize. Furthermore, using K-silicate gave high values of crop growth, grain yield, and quality ${ }^{48}$. In this study, foliar applications of K-silicate at 40,60, and 80 days after sowing recorded the highest values of all the studied characteristics under the regional conditions. These values may be due to the role of $\mathrm{K}$-silicate in increasing the utilization rate and nutrient absorption ${ }^{49}$. Foliar application of K-silicate has also been shown to enhance leaf erectness, increase photosynthesis efficiency, and minimize lodging capability in grasses ${ }^{50}$. Si application increased growth and yield, improved strength, lessened climate stress, supplied impedance to mineral stress ${ }^{51}$, and increased WUE compared to the control ${ }^{52}$.

The increase of growth, yield, quality, and WUE under water stress may be due to the vital role of K-silicate in reducing water-deficit stress on plant growth and yield. These results corroborate those of ${ }^{53}$ who reported that the sorghum yield increased by irrigation with 14-day interval and spraying K-silicate. Thus, Si can mediate drought tolerance ${ }^{51}$. Moreover ${ }^{24}$, observed that the three are increase in growth, yield, protein by foliar application of K-silicate under water stress. Spraying K-silicate has the potential to alleviate the negative effects of drought stress on yield and quality of sugar beet ${ }^{29}$. Si foliar application has bio-stimulative impacts because it alleviates stressful conditions such as salinity, deficiency or excess of water, high and low temperature, and the stout pressure of diseases and pests. Si application to plants is unusual. However, Si fertilization can be effective through foliar application, which is much cheaper and more convenient to use than soil fertilization ${ }^{54}$.Also, foliar application of Si moderated the unfavorable impacts of environmental stresses on the yield of many plants ${ }^{55}$. Research has shown that Se played a critical role in virous plants, eventually afecting crop yield, factors such as starch accumulation in chloroplast, resistance improvement to oxidative stress, postponing of senescence, and water status adjustment under stress conditions and enhnace of antioxidative capacity ${ }^{56}$.

\section{Conclusions}

Form the above obtained results, the addition of K-silicate at the three times through foliar application (40, 60, and 80 days after sowing) at rates $1000 \mathrm{~cm}^{3} / 1$ is beneficial to alleviate the adverse effects of water-deficit stress. The possible mechanism involved in the improvement of growth, yield, and quality characters is the increase of WUE in plants. K supply within this range significantly improved the macronutrient uptake of maize plants. Based on this investigation, under water shortage, we can recommend that the application of K-silicate three time through foliar spraying, which can increase WUE and can result in high grain yield, its components and quality such grain protein content and oil content (\%) under irrigation every 15-day interval under the study conditions and the similar conditions.

Received: 8 September 2020; Accepted: 24 December 2020

Published online: 08 January 2021 


\section{References}

1. Faostat, F. Available online, http://www.fao.org/faostat/en/\#data.QC. Accessed Jan 2018

2. MAL, R. Ministry of Agricultural and Land Reclamation. Economic Affairs Sector, study of statistics for animal, poultry and fish wealth. Egypt.Minist. Agric. Land Reclam., 18, 145-159 (2008).

3. Al-Keraby, F. Egypt country report. Global Agenda for, 73 (2000).

4. El-Beltagy, A. \& Abo-Hadeed, A. The Main Pillars of the National Program for maximizing the Water-Use Efficiency in the Old Land (The Research and Development Council, Ministry of Agriculture and Land Reclamation (MOALR), Giza, Egypt, 2008).

5. Kandil, E. E., Abdelsalam, N. R., Mansour, M. A., Ali, H. M. \& Siddiqui, M. H. Potentials of organic manure and potassium forms on maize (Zea mays L.) growth and production. Sci. Rep. 10, 1-11 (2020).

6. Mohamed, A. E. \& Makki, E. K. Wheat response to irrigation scheduling. Univ. Khartoum J. Agric. Sci. (Sudan) 13(1) (2019),

7. Change, I. P. O. C. Climate change 2007: impacts, adaptation and vulnerability. Genebra, Suiça (2001).

8. Lobell, D. B. \& Field, C. B. Global scale climate-crop yield relationships and the impacts of recent warming. Environ. Res. Lett. 2, 014002 (2007).

9. Tezara, W., Mitchell, V., Driscoll, S. \& Lawlor, D. Water stress inhibits plant photosynthesis by decreasing coupling factor and ATP. Nature 401, 914-917 (1999).

10. Du, N., Guo, W., Zhang, X. \& Wang, R. Morphological and physiological responses of Vitex negundo L. var. heterophylla (Franch.) Rehd. to drought stress. Acta Physiol. Plant. 32, 839-848 (2010).

11. Gholami, R. \& Zahedi, S. M. Identifying superior drought-tolerant olive genotypes and their biochemical and some physiological responses to various irrigation levels. J. Plant Nutr. 42, 2057-2069 (2019).

12. Zahedi, S. M., Moharrami, F., Sarikhani, S. \& Padervand, M. Selenium and silica nanostructure-based recovery of strawberry plants subjected to drought stress. Sci. Rep. 10, 1-18 (2020).

13. Cakir, R. Effect of water stress at different development stages on vegetative and reproductive growth of corn. Field Crops Res. 89, $1-16(2004)$

14. Igbadun, H. E., Tarimo, A. K., Salim, B. A. \& Mahoo, H. F. Evaluation of selected crop water production functions for an irrigated maize crop. Agric. Water Manag. 94, 1-10 (2007).

15. Tariq, J. \& Usman, K. Regulated deficit irrigation scheduling of maize crop. 2009. Sarhad J. Agric. 25, 441-450 (2009).

16. Singh, L. et al. Efficient techniques to increase water use efficiency under rainfed eco-systems. J. AgriSearch 1, 193-200 (2014).

17. Al-Mansor, A., El-Gindy, A., Hegazi, M., El-Bagoury, K. \& Abd El-Hady, S. Effect of surface and subsurface trickle irrigation on yield and water use efficiency of tomato crop under deficit irrigation conditions. Misr J. Agric. Eng. 32, 1021-1040 (2015).

18. Schmidt, R., Zhang, X. \& Chalmers, D. Response of photosynthesis and superoxide dismutase to silica applied to creeping bentgrass grown under two fertility levels. J. Plant Nutr. 22, 1763-1773 (1999).

19. Kandil, E. E., Abdelsalam, N. R., Aziz, A. A. A. E., Ali, H. M. \& Siddiqui, M. H. Efficacy of nanofertilizer, fulvic acid and boron fertilizer on sugar beet (Beta vulgaris L.) yield and quality. SUGAR TECH 22, 782-791 (2020).

20. Liang, Y., Sun, W., Si, J. \& Römheld, V. Effects of foliar-and root-applied silicon on the enhancement of induced resistance to powdery mildew in Cucumis sativus. Plant. Pathol. 54, 678-685 (2005).

21. Hattori, T. et al. Application of silicon enhanced drought tolerance in Sorghum bicolor. Physiol. Plant. 123, 459-466 (2005).

22. Liang, Y., Sun, W., Zhu, Y.-G. \& Christie, P. Mechanisms of silicon-mediated alleviation of abiotic stresses in higher plants: a review. Environ. Pollut. 147, 422-428 (2007).

23. Maghsoudi, K., Emam, Y. \& Ashraf, M. Influence of foliar application of silicon on chlorophyll fluorescence, photosynthetic pigments, and growth in water-stressed wheat cultivars differing in drought tolerance. Turk. J. Bot. 39, 625-634 (2015).

24. Ibrahim, H. I., Sallam, A. M. \& Shaban, K. A. Impact of irrigation rates and potassium silicate fertilizer on seed production and quality of Fahl Egyptian clover and soil properties under saline conditions. Am.-Eurasian J. Agric. Environ. Sci. 15, 1245-1255 (2015).

25. El-Naggar, M. E. et al. Soil application of nano silica on maize yield and its insecticidal activity against some stored insects after the post-harvest. Nanomaterials 10, 739 (2020).

26. Romero-Aranda, M. R., Jurado, O. \& Cuartero, J. Silicon alleviates the deleterious salt effect on tomato plant growth by improving plant water status. J. Plant Physiol. 163, 847-855 (2006).

27. Eneji, A. E. et al. Growth and nutrient use in four grasses under drought stress as mediated by silicon fertilizers. J. Plant Nutr. 31, 355-365 (2008).

28. Liu, J., Han, C., Sheng, X., Liu, S. \& Qi, X. in Oral Presentation at 5th International Conference on Si Agriculature. 13-18.

29. Ali, A. M., Ibrahim, S. M. \& Abou-Amer, I. Water deficit stress mitigation by foliar application of potassium silicate for sugar beet grown in a saline calcareous soil. Egypt. J. Soil Sci. 59, 15-23 (2019).

30. Mosa, W. F., Ali, H. M. \& Abdelsalam, N. R. The utilization of tryptophan and glycine amino acids as safe alternatives to chemical fertilizers in apple orchards. Environ. Sci. Pollut. Res., 1-9. https://doi.org/10.1007/s11356-020-10658-7 (2020).

31. Fouda, M. M. et al. Impact of high throughput green synthesized silver nanoparticles on agronomic traits of onion. Int. J. Biol. Macromol. 149, 1304-1317 (2020).

32. Abdelsalam, N. R. et al. Assessment of silver nanoparticles decorated starch and commercial zinc nanoparticles with respect to their genotoxicity on onion. Int. J. Biol. Macromol. 133, 1008-1018 (2019).

33. Janislampi, K. W. Effect of silicon on plant growth and drought stress tolerance (2012).

34. Balakhnina, T. \& Borkowska, A. Effects of silicon on plant resistance to environmental stresses. Int. Agrophys. 27, 225-232 (2013).

35. Gao, L. et al. Nitrogen fertilizer management and maize straw return modulate yield and nitrogen balance in sweet corn. Agronomy 10, 362 (2020)

36. Page, A., Miller, R. \& Keeney, D. Methods of Soil Analysis. Part 2: Chemical and Microbiological Properties (American Society of Agronomy, Soil Science Society of America, Madison, 1982).

37. Israelsen, D. \& Hansen, V. Flow of water into and through soils. In Irrigation Principles and Practices 3rd edn (Willey, New York, 1962). https://doi.org/10.2136/sssaj1963.03615995002700020010x

38. Kjeldahl, C. A new method for the determination of nitrogen in organic matter. Z. Anal. Chem. 22, 366 (1883).

39. AOAC. Official Methods of Analysis (Association of Official Analytical Chemists, Rockville, 1990).

40. Steel, R. G. Pinciples and procedures of statistics a biometrical approach. Report No. 0070610282 (1997).

41. CoStat, V. Cohort software798 light house Ave. PMB320, Monterey, CA93940, and USA. email: info@ cohort. com and Website: http://www.cohort.com. DownloadCoStatPart2. html (2005).

42. Elgamaal, A. A. \& Maswada, H. F. Response of three yellow maize hybrids to exogenous salicylic acid under two irrigation intervals. Asian J. Crop Sci. 5, 264-274 (2013).

43. Shi, Q., Zeng, X., Li, M., Tan, X. \& Xu, F. Effects of different water management practices on rice growth. Water-Wise Rice Prod. 1, 3-14 (2002).

44. Comas, L. H., Trout, T. J., DeJonge, K. C., Zhang, H. \& Gleason, S. M. Water productivity under strategic growth stage-based deficit irrigation in maize. Agric. Water Manag. 212, 433-440 (2019).

45. Song, L., Jin, J. \& He, J. Effects of severe water stress on maize growth processes in the field. Sustainability 11, 5086 (2019).

46. Zhang, H. et al. Response of maize yield components to growth stage-based deficit irrigation. Agron. J. 111, 3244-3252 (2019). 
47. Shedeed, S. I. Assessing effect of potassium silicate consecutive application on forage maize plants (Zea mays L.). J. Innov. Pharm. Biol. Sci. 5, 119-127 (2018).

48. Mikhael, B., Awad-Allah, M. \& Gewaily, E. Effect of irrigation intervals and silicon sources on the productivity of broadcast-seeded Sakha 107 rice cultivar. J. Plant Prod. 9, 1055-1062 (2018).

49. Ren, J., Guo, J., Xing, X., Qi, G. \& Yuan, Z. Preliminary study on yield increase effects and yield increase mechanism of silicate fertilizer on maize. J. Maize Sci. 10, 86-87 (2002).

50. Ahmad, A., Afzal, M., Ahmad, A. \& Tahir, M. Effect of foliar application of silicon on yield and quality of rice (Oryza Sativa L). Cercet. Agron. Mold. 46, 21-28 (2013).

51. Pilon, C., Soratto, R. P. \& Moreno, L. A. Effects of soil and foliar application of soluble silicon on mineral nutrition, gas exchange, and growth of potato plants. Crop Sci. 53, 1605-1614 (2013).

52. Abdeen, S. \& Mancy, A. A melioration of water stress effect on sorghum plant growth and water use efficiency by application of potassium silicate and salicylic acid. Bull. Fac. Agric. Cairo Univ. 69, 43-52 (2018)

53. Sepaskhah, A. R. \& Khajehabdollahi, M. H. Alternate furrow irrigation with different irrigation intervals for maize (Zea mays L.). Plant Prod. Sci. 8, 592-600 (2005).

54. Artyszak, A. Effect of silicon fertilization on crop yield quantity and quality-a literature review in Europe. Plants 7, 54 (2018).

55. Zahedi, S. M., Karimi, M. \& Teixeira da Silva, J. A. The use of nanotechnology to increase quality and yield of fruit crops. J. Sci. Food Agric. 100, 25-31 (2020).

56. Hasanuzzaman, M., Alam, M. M., Nahar, K., Ahamed, K. U. \& Fujita, M. Exogenous salicylic acid alleviates salt stress-induced oxidative damage in Brassica napus by enhancing the antioxidant defense and glyoxalase systems. Aust. J. Crop Sci. 8, 631 (2014).

\section{Acknowledgements}

The authors gratefully acknowledge the Researchers Supporting Project Number (RSP-2020/123), King Saud University, Riyadh, Saudi Arabia.

\section{Author contributions}

Data curation, E.E.K. and A.A.M.Z.E.-D.; formal analysis, M.A.-D.; investigation, G.M.A., E.E.K. and H.M.A.; methodology, A.A.M.Z.E.-D. and M.A.-D.; project administration, G.M.A.; resources, E.E.K. and M.A.-D.; software, H.M.A.; writing-original draft, H.M.A. and N.A.; writing-review \& editing, N.A.

\section{Funding}

This research was funded by King Saud University, Grant Number RSP-2020/123" funded by King Saud University, Riyadh, Saudi Arabia.

\section{Competing interests}

The authors declare no competing interests.

\section{Additional information}

Correspondence and requests for materials should be addressed to E.E.K. or N.R.A.

Reprints and permissions information is available at www.nature.com/reprints.

Publisher's note Springer Nature remains neutral with regard to jurisdictional claims in published maps and institutional affiliations.

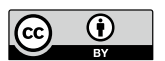

Open Access This article is licensed under a Creative Commons Attribution 4.0 International License, which permits use, sharing, adaptation, distribution and reproduction in any medium or format, as long as you give appropriate credit to the original author(s) and the source, provide a link to the Creative Commons licence, and indicate if changes were made. The images or other third party material in this article are included in the article's Creative Commons licence, unless indicated otherwise in a credit line to the material. If material is not included in the article's Creative Commons licence and your intended use is not permitted by statutory regulation or exceeds the permitted use, you will need to obtain permission directly from the copyright holder. To view a copy of this licence, visit http://creativecommons.org/licenses/by/4.0/.

(C) The Author(s) 2021 